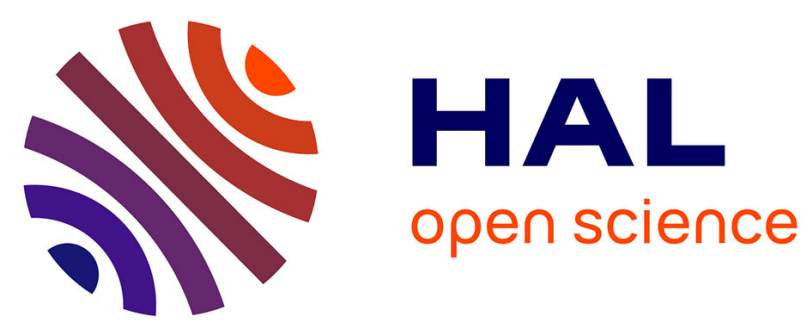

\title{
Lactuca sativa growth in compacted and non-compacted semi-arid alkaline soil under phosphate fertilizer treatment and cadmium contamination
}

\author{
Valérie Azzi, Ali Kanso, Véronique Kazpard, Ahmad Kobeissi, Bruno
}

Lartiges, Antoine Samrani

\section{To cite this version:}

Valérie Azzi, Ali Kanso, Véronique Kazpard, Ahmad Kobeissi, Bruno Lartiges, et al.. Lactuca sativa growth in compacted and non-compacted semi-arid alkaline soil under phosphate fertilizer treatment and cadmium contamination. Soil and Tillage Research, 2017, 165, pp.1-10. 10.1016/j.still.2016.07.014 . hal-02265691

\section{HAL Id: hal-02265691 \\ https://hal.science/hal-02265691}

Submitted on 11 Aug 2019

HAL is a multi-disciplinary open access archive for the deposit and dissemination of scientific research documents, whether they are published or not. The documents may come from teaching and research institutions in France or abroad, or from public or private research centers.
L'archive ouverte pluridisciplinaire HAL, est destinée au dépôt et à la diffusion de documents scientifiques de niveau recherche, publiés ou non, émanant des établissements d'enseignement et de recherche français ou étrangers, des laboratoires publics ou privés. 


\section{Lactuca sativa growth in compacted and non-compacted semi-arid alkaline soil under phosphate fertilizer amendment and cadmium contamination}

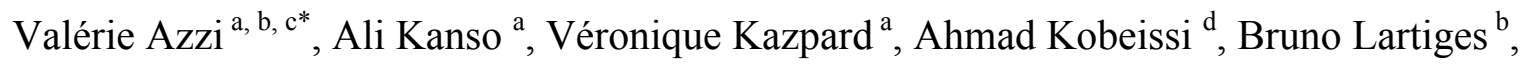
Antoine El Samrani ${ }^{\text {a }}$

${ }^{a}$ Platform for Research and Analysis in Environmental Sciences, Doctoral School of Science and Technology, Faculty of Sciences, Hadath Campus, Po. Box. 5. antoineelsamrani@ul.edu.lb, ahkobeissi@ul.edu.lb, kveronique@ul.edu.lb

${ }^{\mathrm{b}}$ University of Toulouse (Paul Sabatier), Geosciences Environment Toulouse (UMR CNRS-UPS 5563 IRD 234), 14 Av. E. Belin, 31400 Toulouse, France. bruno.lartiges@get.obs-mip.fr

${ }^{\mathrm{c}}$ Lebanese Agriculture Research Institute (LARI), Fanar, Lebanon. valerie.azzi@hotmail.com

${ }^{d}$ Faculty of Sciences, Lebanese University, Hadath Campus, Po. Box. 5. ahkobeissi@ul.edu.lb

*Corresponding author: Platform for Research and Analysis in Environmental Sciences, Doctoral School of Science and Technology, Faculty of Sciences, Lebanese University, P.O Box. 5, Campus Rafic Hariri-Beirut- Lebanon. Tel: $+961 \quad 5 \quad 470 \quad 936$ ext. 121. valerie.azzi@hotmail.com 


\section{ABSTRACT}

Soil compaction is known to drastically modify soil properties and hence to affect both plants growth and metals distribution in the soil. Phosphate amendment is generally used to improve plants production but unfortunately it also gives rise to higher metal contamination in soils and plants. In this study, the effects of various parameters on the growth of Lactuca sativa including soil density, phosphate fertilization and cadmium contamination, were investigated. In particular, the migration of cadmium in the soil columns, its accumulation and translocation in lettuces were also examined. Lactuca sativa was selected as a model plant because it is widely cultivated in alkaline clay soils of eastern Mediterranean countries. Two levels of soil compaction (1.2 and 1.4

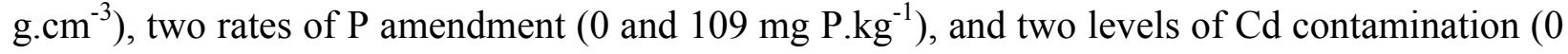

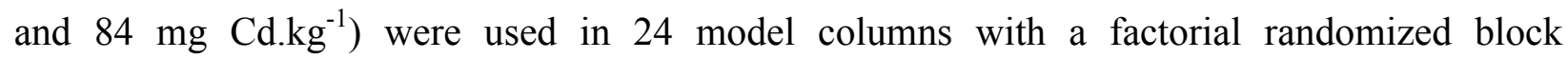
experimental design. Soil compaction increased considerably both leaf area and dry weight of roots and shoots, whereas both chlorophyll content and NRA decreased. For the two soil bulk densities, the phosphate fertilizer improved lettuce growth characterized by plant height, dry matter, leaf number and NRA, whereas Cd contamination altered those parameters and increased the chlorophyll content. In soils contaminated with cadmium, the combination of compaction and phosphate fertilization resulted in a significant decrease in $\mathrm{Cd}$ migration along the soil columns. $\mathrm{Cd}$ uptake by plants increased in $\mathrm{Cd}$ treated soils; its accumulation was found to be more important than in plants grown in P-Cd treated soil where $\mathrm{Cd}$ uptake was clearly reduced in shoots and roots.

Keywords: Soil density, phosphate fertilizer, cadmium, Lactuca sativa, chlorophyll, NRA 


\section{INTRODUCTION}

Mechanization of agriculture and addition of chemical fertilizers have been the typical responses to increase crop yields and to improve soil fertility. However, such approaches have led to significant soil compaction and soil structure deterioration. According to the literature, soil compaction is one of the main factors that influences soil physical, microbial and biochemical properties (Barzegar, et al. 2006; Rosolem et al., 2002). Soil compaction increases soil bulk density, soil mechanical resistance, and surface runoff; it also reduces soil porosity and modifies the pore size distribution in the soil profile (Kulli et al., 2003; Zhang et al., 2006). The increase in soil compaction strongly influences plant productivity and crop growth rate by reducing roots growth and their penetration into the soil, thus reducing water and air availability as well as ions transfer to roots and nutrients uptake (Barzegar et al., 2000; Chen et al., 2014; Głąb, 2014; Kuncoro et al., 2014; Miransari et al., 2009).

If porosity reduction by compaction is a common problem encountered in plough soils (Kuncoro et al., 2014; Lipiec et al., 2012), chemical fertilizers amendment has represented the main practice to improve the agriculture productivity. Thus, leaf surface area, leaf mass ratio and leaf area ratio of an Oleaceae species (Fraxinus angustifolia Vahl.) cultivated in a loamy soil were increased in a compacted soil as a result of increased amount of nutrients per volume unit (Alameda and Villar 2009, 2012; Arvidsson 1999). Unfortunately, intensive phosphate fertilization has conducted to the accumulation of trace metals such as zinc, cadmium, and lead in cultivated soils (Jiao et al., 2012; Lavado et al., 2001; Azzi et al. 2016). Metallic contaminants are transferred to cropland and subsequently along the food chain, which represents a critical environmental issue (Giuffré et al., 1997; Jiao et al., 2012; Nicholson et al., 2003; Luo et al., 2009). Soil compaction has been shown to inhibit nutrients transfer to plants; it thus limits the 
availability and the uptake of major nutrients $(\mathrm{N}, \mathrm{P}, \mathrm{K}, \mathrm{Ca}, \mathrm{Mg}$ and $\mathrm{S})$ and micronutrients $(\mathrm{Mn}$, Fe, $\mathrm{Zn}$ and $\mathrm{Cu}$ ) (Barzegar et al., 2006; Lipiec and Stępniewski, 1995; Miransari et al., 2009; Zhao et al., 2007). Obviously, soil compaction also affects trace metals bioavailability (Basta et al., 2001; Qiu et al., 2011). In the case of Trifolium alexandrimum, soil compaction reduced both $\mathrm{P}$ and $\mathrm{Zn}$ uptakes (Barzegar et al., 2006). In addition, high levels of phosphorus in soil may also slow down the uptake of trace contaminants by plants, as illustrated by Pteris vittata in presence of arsenic (Bolan et al., 2003a; Huang et al., 2007; Qiu et al., 2011; Yu and Zhou, 2009)

Cadmium has been identified as the most common toxic element that readily reaches the food chains because of its great bioavailability. It accumulates in large amounts in plant tissues without showing any noticeable toxic signs (Grant and Bailey, 1997; Renella et al., 2004). Previous studies of phosphate interaction with cadmium in cultivated soils evidenced antagonistic results. Pot cultivation with various crops revealed that cadmium uptake by plants was inhibited in presence of phosphate (He and Singh, 1994; Naidu et al., 1994; Yu and Zhou, 2009). Unexpectedly, soil Cd phytoextractability and Cd uptake by Raphanus sativa L. were found to be increased with superphosphate use in the field (Hong et al., 2008). Cadmium bioavailability depends on soil $\mathrm{pH}$, organic matter content, clays and iron oxides/hydroxides contents (François et al., 2009; Grant et al., 2010; Williams and David, 1976). However, little attention has been given to the influence of soil compaction and phosphate fertilization on the cadmium behaviour in soil and its influence on plant growth.

The main goal of this study is to investigate the effects of soil compaction on Lactuca sativa growth in presence of phosphate fertilizer and cadmium. Lactuca sativa is the main leafy vegetable in mediterranean cooking and is intensively cultivated in Eastern Mediterranean countries. In the Beaqaa valley, around 1500 hectares are annually cultivated with Lactuca sativa 
(Karam et al., 2002). The accumulation and translocation of $\mathrm{Cd}$ in plants and its distribution in compacted and non-compacted soil columns are simultaneously investigated to provide evidences of physiological and morphological modifications in the plants.

\section{EXPERIMENTAL SECTION}

\subsection{Soil sampling}

A typical Mediterranean terra rosa soil was selected for this study. Soil samples were collected in the Ammik plain, a semi-arid region located in the western Bekaa valley in Lebanon (Lat. 33 $44^{\prime}$ 17.2' N, Long. $35^{\circ} 46^{\prime} 49.8^{\prime \prime}$ E). No anthropogenic activity (agriculture and industry) has been reported for this sampling site. The soil was collected over an area of $50 \mathrm{~m}^{2}$ and at a depth between 0 and $50 \mathrm{~cm}$. It was then air-dried at ambient room temperature, crushed and sieved through a $7 \mathrm{~mm}$ mesh sieve to remove coarse fragments, and finally homogenized.

The main physical and chemical properties of the soil were determined following standard methods listed in Table 1. To determine the trace metals content, soil samples were mineralized and digested using an aqua regia digestion $\left(\mathrm{HNO}_{3}: \mathrm{HCl}_{\mathrm{v} / \mathrm{v}} 1: 3\right)$. The concentrations of $\mathrm{Cd}, \mathrm{Zn}, \mathrm{Cu}$, $\mathrm{Pb}, \mathrm{Ca}, \mathrm{Al}$ and $\mathrm{Fe}$ in the digested soil solutions were determined by Atomic Absorption Spectrometry (AAS) using a Rayleigh WXF-210 AA Spectrophotometer and WF-10A Autosampler. All reagents were of analytical grade and each value reported is the average of triplicate determinations.

\subsection{Experiment design}

Two soil bulk densities, 1.2 and $1.4 \mathrm{~g} . \mathrm{cm}^{-3}$, were selected to assess the effects of soil compaction on Lactuca sativa growth in the presence of phosphate fertilizer and cadmium contaminant. A $2 \times 2 \times 2$ factorial randomized block experimental design was used with three replicate columns per treatment. Eight treatments were prepared by combining two soil bulk densities, two rates of $\mathrm{P}_{2} \mathrm{O}_{5}$ amendment and two Cd concentrations. The $1.2 \mathrm{~g} \cdot \mathrm{cm}^{-3}$ bulk density is representative of the 
density of a clay soil. The $1.4 \mathrm{~g} . \mathrm{cm}^{-3}$ bulk density is selected to evaluate the effect of an increased compaction on plant growth since a 1.39 g.cm ${ }^{-3}$ density affects root growth according the USDA. A single superphosphate $\left(18 \% \quad \mathrm{P}_{2} \mathrm{O}_{5}\right)$, graciously provided by the 'Lebanon Chemicals Company-LCC,' was used as fertilizer. It was added to provide two phosphorus levels

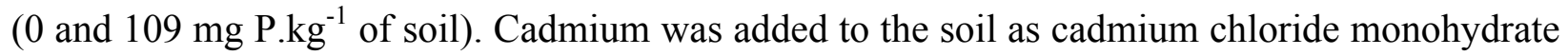

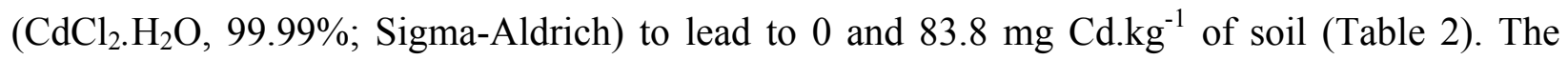
content of metals identified in the superphosphate fertilizer was negligible; $\mathrm{Pb}, \mathrm{Cd}, \mathrm{Zn}$ and $\mathrm{Cu}$ levels were respectively $10 \pm 0.2,5.1 \pm 0.8,92.26 \pm 12$ and $6 \pm 0.5 \mathrm{mg} \cdot \mathrm{kg}^{-1}$ of fertilizer, which leads to very low added contents considering the amount of fertilizer added (Kratz et al., 2016). The soils without $\mathrm{P}$ and $\mathrm{Cd}$ additions were used as control samples.

Cylindrical PVC tubes of $19.5 \mathrm{~cm}$ internal diameter and $45 \mathrm{~cm}$ high were used. The soil was deposited horizontally into the PVC columns in three layers of $10 \mathrm{~cm}$ thick and then two layers of $5 \mathrm{~cm}$ thick, and compacted according to Jusoff method (1991). An increasing load was applied five times to obtain the desired bulk density. When phosphorus and cadmium were added to the soil, they were both mixed with the upper $5 \mathrm{~cm}$ layer of soil before being transferred to the columns. The pot experiment was conducted in a greenhouse of controlled temperature and humidity.

\subsection{Plant growth and samples preparation}

The seeds of lettuce (Lactuca sativa) were pre-germinated for 2 weeks at $20^{\circ} \mathrm{C}$ in a mixture of perlite and coconut husk. One seedling was then transplanted into each column. The 24 columns were each irrigated with $750 \mathrm{ml}$ of mineral water per week. Irrigation water was previously characterized (electrical conductivity of $297 \mu{\mathrm{S} . \mathrm{cm}^{-1}}^{-}$(at $25^{\circ} \mathrm{C}$ ), $\mathrm{pH} 7.5, \mathrm{HCO}^{3-} 195 \mathrm{mg}^{-1}, \mathrm{Ca}^{2+}$ $67 \mathrm{mg} . \mathrm{l}^{-1}, \mathrm{Mg}^{2+} 1.45 \mathrm{mg} \cdot \mathrm{l}^{-1}, \mathrm{Na}^{+} 4 \mathrm{mg} . \mathrm{l}^{-1}, \mathrm{~K}^{+} 0.2 \mathrm{mg} \cdot \mathrm{l}^{-1}$ and $\left.\mathrm{Cl}^{-} 6.5 \mathrm{mg} . \mathrm{l}^{-1}\right)$. The leachates of each 
column were collected in separate polyethylene containers the third, the fifth and the seventh week after planting.

The lettuces were grown for 77 days under controlled conditions, i.e. temperature set to $21 / 19{ }^{\circ} \mathrm{C}$ day/night, $12 \mathrm{~h}$ of light period and $60-70 \%$ air moisture. The shoots of each column were then harvested while the roots were carefully removed from the soil and washed with distilled water. Leaf number, leaf area, plant height, maximum root length and leaf length, stems and roots fresh weight were measured. The roots and shoots were then dried at $80^{\circ} \mathrm{C}$ for 48 hours in a ventilated oven, and the dry mass of each part was subsequently determined.

Finally, the PVC columns were cut lengthwise and divided into 6 layers from the upper bottom, i.e. 4 layers of $5 \mathrm{~cm}$ thick and the last 2 layers of $10 \mathrm{~cm}$ thick. Once sliced, the soil layers were individually air-dried in a dark room for seven days followed by 2 days at $40^{\circ} \mathrm{C}$. The samples were then sieved through a $2 \mathrm{~mm}$ mesh and digested to investigate the $\mathrm{Cd}$ distribution in the soil.

\subsection{Total chlorophyll content}

During the last days of the experiment, leaf discs were taken from each plant to determine the total chlorophyll content. Each leaf section was first immersed in $80 \%$ acetone for $24 \mathrm{~h}$ in dark room at $20^{\circ} \mathrm{C}$, and the total chlorophyll content $\mathrm{Chl}(\mathrm{a}+\mathrm{b})$ was then determined by measuring the absorbance at 645 and $663 \mathrm{~nm}$ (spectrophotometer Thermo Spectronic 20 Genesys). The calculation was based on the method described by Arnon (1949).

\subsection{Nitrate reductase activity (NRA)}

A sub-sample of fresh leaves was used to determine the nitrate reductase activity according to Jaworski (1971). The analyses were performed in triplicate. A $0.5 \mathrm{~g}$ sample of fresh leaf tissue was sliced into small pieces and incubated with phosphate buffer $(\mathrm{pH} 7.5)$, and then with potassium nitrate $(0.03 \mathrm{M})$ and isopropanol solutions $(5 \%)$ for $2 \mathrm{~h}$ at $28^{\circ} \mathrm{C}$. The nitrite content 
(NRA in $\mu$ mole $\mathrm{NO}_{2} \cdot \mathrm{g}^{-1} \cdot \mathrm{h}^{-1}$ ) was determined colorimetrically at $540 \mathrm{~nm}$ after addition of N-1 naphthylethylenediamine dihydrochloride $(0.02 \%)$ and sulphanilamide (1\%).

\subsection{Heavy metals in soil layers and leachate water samples}

For heavy metal analysis, soil sub-samples were digested with aqua regia $\left(3: 1 \mathrm{HCl} / \mathrm{HNO}_{3}(\mathrm{v} / \mathrm{v})\right)$ according to ISO $11466: 1995$. The $\mathrm{Cd}, \mathrm{Pb}$, and $\mathrm{Zn}$ concentrations of digested solutions were then analyzed by Flame Atomic Absorption Spectrometry (Rayleigh WFX-210 AA Spectrophotometer).

$\mathrm{pH}$ and electrical conductivity were measured in all leachates. After filtration with $0.45 \mu \mathrm{m}$ filters, the anions concentrations $\left(\mathrm{Cl}^{-}, \mathrm{NO}_{3}{ }^{-}\right.$and $\left.\mathrm{SO}_{4}{ }^{2-}\right)$ of leachates were obtained by ion chromatography (Shimadzu Shim-pack IC-A3) equipped with a conductivity detector CDD10AVP. Heavy metals in leachates $(\mathrm{Cd}, \mathrm{Pb}$ and $\mathrm{Zn})$ were also analyzed using AAS.

\subsection{Accumulation, translocation and bioaccumulation of heavy metals}

The dried soil samples were homogenized by grinding using a stainless steel blender. A sample mass between 50 to $1000 \mathrm{mg}$ of each plant part, was digested in $20 \mathrm{ml} \mathrm{HNO}_{3}$. The heavy metals concentrations in the various parts of the plants were then analyzed using AAS. The cadmium translocation factor from roots to shoots $\left(\mathrm{F}_{\mathrm{T}}\right)$, was described as the ratio of $\mathrm{Cd}$ concentration in the shoot to the $\mathrm{Cd}$ concentration in the $\operatorname{root}\left(\mathrm{F}_{\mathrm{T}}=[\mathrm{Cd}]_{\text {shoot }} /[\mathrm{Cd}]_{\text {root }}\right)$. Bioaccumulation factors $\left(\mathrm{F}_{\mathrm{B}}\right)$ were obtained as the ratio between the concentrations of $\mathrm{Cd}$ in shoot tissue and those in the soil $\left(\mathrm{F}_{\mathrm{B}}=[\mathrm{Cd}]_{\text {shoot }} /[\mathrm{Cd}]_{\text {soil }}\right)($ Durand et al., 2015).

\subsection{Statistical analyses}

All data were analyzed using SPSS statistics 17.0. Two-way ANOVA (generalized linear models) was used at $\mathrm{P}<0.05$ to assess the statistical significance effects of soil compaction, phosphorus, 
cadmium and their interactive effects. Duncan multiple range test $(\alpha=5 \%)$ was performed to analyze statistical differences between different treatments for each parameter.

\section{RESULTS AND DISCUSSION}

The soil used in this study is a typical Mediterranean clay soil based on USDA textural diagram. It is a medium to fine textured soil of high clay content (53\%) and has a CEC of about 19 meq/100g. The soil is of moderate salinity (electrical conductivity $1.157 \mathrm{mS} . \mathrm{cm}^{-1}$ ), shows a very low content in organic matter $(\mathrm{OM})(2.082 \%)$ and a relatively low total calcareous (about $1.4 \%)$, which is consistent with the alkaline soil $\mathrm{pH}(8.21)$ (Table 1). Accordingly, the amount of clayOM complexes is expected to be low and soil compaction should easily take place affecting capillarity and water availability to roots (Kooistra et al., 1992). The levels of $\mathrm{Zn}, \mathrm{Cu}, \mathrm{Pb}$, and $\mathrm{Cd}$ were under the maximum allowed limits by USEPA, 1997. The high levels in iron and aluminum were expected for a clay terra Rosa Mediterranean soil.

\subsection{Crop growth}

\subsubsection{Leaf growth}

As shown in Table 3, the leaf number was not affected by soil compaction even when cadmium was added to the soil column, whereas a significant increase in leaf number $(\mathrm{P}<0.05)$ was observed in lettuces treated by phosphorus fertilizer (P). Moreover, in compacted soil (C) treated with P (C-P), plants showed a significant increase in leaf area. The highest leaf area $\left(1635.1 \mathrm{~cm}^{2}\right.$ \pm 321.2) was found for the treatments receiving $\mathrm{P}$ in soils of $1.4 \mathrm{~g} . \mathrm{cm}^{-3}$ bulk density. Several studies have shown that the application of phosphate significantly increases leaf number, leaf elongation and leaf area of Lolium perenne, maize (Zea mays L.), soybean and wheat (Triticum aestivum L.) (Assuero et al., 2004; Chiera et al., 2002; Kavanová et al., 2006; Rodriguez et al. 1998). In addition, compaction has been shown to enhance the contact between roots and 
substrate, thus determining an increase in the volume of root cells related to the higher amounts of nutrients per unit volume of soil and a greater water availability (Arvidsson, 1999; Barzegar et al., 2006). Such conditions have also been shown to enhance the development of leaf area for seven woody plants (Alameda and Villar, 2009).

\subsubsection{Root development}

Soil compaction resulted in a decrease in root length for all treatments with or without the presence of phosphate fertilizer and cadmium. Root length was reduced by $29.3 \%$ between plants growing in non-compacted and compacted soil treated with P (NC-P and C-P) (Table 3). These results are in line with those of Lipiec et al. (2012) showing a reduction by more than $50 \%$ of root length between compacted and non-compacted soil (Grzesiak et al., 2013; Rosolem et al., 2002). Soil compaction delays roots development and increases the resistance to roots penetration (Konopka et al., 2008). In addition, the availability of oxygen decreases and becomes a limiting factor the normal activity of roots (Arvidsson, 1999). Nevertheless, P addition leads to an increase in root length in both compacted and non-compacted soils. Thus, root length of NC-P was 1.57 times longer than that of control NC. Phosphorus as phospholipids is a constituent of plant cell membrane that it is concentrated in the fast growing parts of plants particularly in the root tips. Furthermore, it stimulates the development and elongation of root systems (Al-Niemi et al., 1998; Naeem et al., 2010).

\subsubsection{Plant height}

After 77 days of growth, the variation in soil bulk density was unsignificant on aboveground length for all treatments. The decrease in root length development observed in compacted soils, was compensated by a higher dry weight of roots revealing a higher nutrients uptake (Table 3 ). In contrast, the applications of phosphate and cadmium had a significant effect on lettuce height 
$(\mathrm{P}<0.05)$. Superphosphate amendment significantly enhanced shoot length by 1.2 times higher than those cultivated in both $\mathrm{C}$ and $\mathrm{NC}$ soil. Such increase results from the stimulating effect of phosphorus on root development leading to a beneficial nutrient absorption.

Cadmium application had a strong negative impact on plant height. Thus, shoot height decreased by 21 and 30\% for C-Cd and NC-Cd tests, respectively, in comparison with the corresponding blanks. The growth inhibition induced by a cadmium treatment is generally attributed to a perturbation of hormonal activity, especially that related to abscisic acid. The high affinity of cadmium for sulfahydryl proteins groups may also delay the lettuce growth. Such observations are consistent with previous studies reporting that plant height, leaf area and plant weight are reduced in the presence of cadmium (Chaffei et al., 2004; Dong et al., 2005; Greger and Örgen, 1991).

The presence of phosphorus mitigates the negative effect of cadmium since the plant heights in (C-P-Cd) and (NC-P-Cd) tests were equivalent to those of (C) and (NC) controls. Phosphorus application promotes $\mathrm{Cd}$ immobilization in the soil through the formation of cadmiumorthophosphate complexes, thus decreases the availability, of $\mathrm{Cd}$ to plants.

\subsubsection{Dry weight of shoots and roots}

While both soil compaction and P application enhanced lettuce growth and increased the dry weight of roots and shoots, Cd application led to a significant decrease in shoot dry weight (Table 3). Shoots and roots dry weight increased on average by $36 \%$ and $33 \%$ respectively, in compacted soil (C) compared with non-compacted (NC) soil. The highest shoot and root dry weight was recorded in compacted soil treated with P (C-P). Such increase in biomass of aerial and subterranean parts can be related to the role of phosphorus in the development of a more extensive root system, which allows an increase of nutrient and water absorption (Naeem et al., 
2010). The lowest dry weight was obtained for the NC-Cd treatment (Table 3). In that case, the reduction in dry weight is attributed to the effect of $\mathrm{Cd}$ on the enzymatic activities regulating growth and physiological behavior: inhibition of water transport to the stem, decrease of essential elements uptake, reduced stomata openings and limited $\mathrm{CO}_{2}$ absorption, are the principal factors that cause the reduction of biomass (Chaffei et al., 2004; Greger and Örgen, 1991; Grzesiak et al., 2013).

\subsubsection{Chlorophyll content}

The soil compaction was unsignificant on the chlorophyll content in both $\mathrm{C}$ and $\mathrm{N}-\mathrm{C}$ treatments. The most pronounced physiological response of lettuce to the various treatments was observed for the soils treated with $\mathrm{Cd}$, especially that of compacted soil (C-Cd) (Table 4). Plants grown in the presence of cadmium (C-Cd and NC-Cd) or in the presence of $\mathrm{Cd}$ and superphosphate (C-PCd and NC-P-Cd), had significantly higher chlorophyll contents than those of controls and plants only treated with the phosphate fertilizer (C-P, NC-P), which implies a relationship between cadmium contamination and chlorophyll production. Such result is in agreement with that of Manios et al. (2003), who reported an increase in total chlorophyll for Typha latifolia plants after irrigation with solutions containing various concentrations of $\mathrm{Cd}, \mathrm{Cu}, \mathrm{Ni}, \mathrm{Pb}$ and $\mathrm{Zn}$. In that case, the increase in chlorophyll content was attributed to a change in the activity of hormones involved in chlorophyll synthesis . Furthermore, the reduction of leaf surface was correlated with the accumulation of chlorophyll pigments. Treating bean plants with Cd, Skórzyńska-Polit and Baszyński (1997) observed a disruption of thylakoid membranes in comparison with those of control. Nonetheless, soil compaction had significantly decreased the chlorophyll concentration for plants grown in the presence of superphosphate (C-P) and superphosphate with cadmium (CP-Cd) in comparison with the same treatments for non-compacted soil (the last four treatments). 
Kozlowski (1999) mentioned a reduction of the rate of photosynthesis, i.e. a reduction in chlorophyll content, for two trees species (Rubus sp. and Pinus contorta) grown in compacted soils, but such observation had never been previously reported for Compositae species (Lactuca sativa). A significant increase in chlorophyll concentration was also observed for lettuces grown in non-compacted soil treated with superphosphate (NC-P). Such result is consistent with those of Jiang et al. (2007) and Castillo-Michel et al. (2009) who showed that phosphate increases the chlorophyll content in leaves, and hence improves the nutritional quality and the plant photosynthesis ability. Similar increases in chlorophyll contents resulting from P applications, have also been reported by Naeem et al (2010).

\subsubsection{Nitrate reductase Activity}

Soil compaction led to a significant decrease in nitrate reductase activity (NRA) for all applied treatments except for the $\mathrm{C}$ and $\mathrm{NC}$ controls. A significant reduction of $17.8 \%$ was observed between NC-P and C-P (Table 4). Soil compaction is involved in nitrate leaching which promotes denitrification. In addition, it contributes to root shortening and hence to a decrase of nutrients uptake, especially nitrates. All these factors contribute to the reduction of the nitrate reductase activity in compacted soils. The observed results are in accordance with those of Goupil et al. (1998) who observed a decrease in NRA in the presence of mechanical stress. As previously shown for the compacted soils, cadmium significantly reduced the NRA of plants grown in presence of $\mathrm{Cd}$ (C-Cd, NC-Cd, C-P-Cd and NC-P-Cd). NRA decreased from 105.45 to $63.93 \mathrm{~mol} \mathrm{NO}_{2}^{-} \mathrm{g}^{-1} \mathrm{~h}^{-1}$ between $\mathrm{C}$ and $\mathrm{C}-\mathrm{Cd}$. The cadmium toxicity to plants influenced both nitrate absorption and transport from the roots to the leaves, and then led to a reduction in nitric oxide assimilation (Chaffei et al., 2004; DalCorso et al., 2008). This also affects the activity of various enzymes involved in the nitrogen metabolism within the leaf such as glutamine 
synthetase-glutamate synthase pathway and glutamate dehydrogenase (Chaffei et al., 2004). In comparison with other treatments, plants treated with superphosphate (C-P and NC-P) showed a significant incrase in NRA ( $35 \%$ and 38\% greater than that of C and NC controls, respectively). Such increase is due to the positive effect of $\mathrm{P}$ in plant metabolism. Indeed, it has been shown that NRA is enhanced by the application of mineral nutrients, especially phosphorus (Lillo, 1994a, b; Campbell, 1999). Mineral nutrients were also found to improve nitrate assimilation in castor beans and soybean (Jeschke et al., 1997; Rufty Jr. et al., 1993).

\subsection{Cd distribution along the soil columns}

After 77 days, the Cd concentration in the soil columns was determined as a function of depth for all treatments. A surprising effect of soil compaction was observed below the $0-5 \mathrm{~cm}$ layer $(\mathrm{C}-\mathrm{Cd}$ and NC-Cd tests). The Cd content in the compacted soil was only half $\left(17.7 \pm 0.9 \mathrm{mg} \cdot \mathrm{kg}^{-1}\right)$ of that of the non-compacted soil (35.6 $\left.\pm 3.4 \mathrm{mg} \cdot \mathrm{kg}^{-1}\right)$ in the $5-10 \mathrm{~cm}$ layer (Fig. 1a). Therefore, soil compaction delayed the migration of $\mathrm{Cd}$ from the $5-10 \mathrm{~cm}$ layer to the $10-15 \mathrm{~cm}$ layer. Similarly, but to a lesser extent, in the soil treated with the phosphate fertilizer, the migration of $\mathrm{Cd}$ from the $0-5 \mathrm{~cm}$ layer to the $5-10 \mathrm{~cm}$ layer was less in compacted (C-P-Cd) than in non-compacted soil (NC-P-Cd) by about $7 \%$ and $21 \%$, respectively (Fig. 1b). In all cases, the geochemical background level for $\mathrm{Cd}$ is reached below the $10-15 \mathrm{~cm}$ layer. The $\mathrm{Cd}$ behaviour in the soil is mainly related to the soil density as well as to the phosphate content. Hence, it can be inferred that phosphate fertilizer and compaction are key factors in reducing cadmium migration since PCd complexes can be formed (Bolan et al., 2003a; Bolan et al., 2003b; Hong et al., 2008, Jiang et al., 2007). Nevertheless, soil compaction, with or without phosphate treatment, can be considered as the main physical barrier that increases the metal retention in the upper soil layers. 


\subsection{Leachates composition}

Leachates were characterized at the $3^{\text {rd }}$, the $5^{\text {th }}$ and the $7^{\text {th }}$ week. The $\mathrm{pH}$ of first leachates sampled varied between 8 and 8.2, the values of second leachates varied between 8.3 and 8.45 and those of third leachates were between 8.38 and 8.7 (Fig. 2a). However, such pH increase remains moderate and may simply be attributed to a $\mathrm{CO}_{2}$ decrease in the soil (Summerfelt et al., 2003).

In contrast, the electrical conductivity (EC) decreased between the first and the third leachate

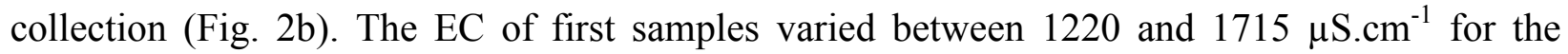
various treatments, whereas those of the third leachate decreased from 963.33 to $656 \mu \mathrm{S} . \mathrm{cm}^{-1}$. Under such conditions, the formation of metal hydroxides may occur thus decreasing the leachate conductivity (Rich et al., 2008).

The nitrate concentrations in the three leachates were greater for compacted soils compared with those of non-compacted soils (Fig. 3a). In particular, a decrease in nitrate concentration from 499 to $342 \mathrm{mg} . \mathrm{l}^{-1}$ can be observed between C-Cd and NC-Cd. Previous studies by Barzegar et al. (2006) has suggested that compaction may facilitate nitrate migration. The observed decrease in nitrate concentration between consecutive leachates may be the result of combined factors, such as the denitrification in anaerobic conditions (deep soil columns), soil biomass metabolisms, nitrate leaching and nitrate assimilation by plant as a function of time (Lipiec and Stępniewski, 1995; Arvidsson, 1999).

In contrast, chloride and sulfate concentrations were higher in leachates from non-compacted soils (Fig. 3b, 3c). In the first leachate, soil compaction determined a $68 \%$ and $12 \%$ decrease in chloride and sulfate, respectively. Indeed, soil compaction alters soil water retention and decreases infiltration ability, thus leading to a decrease in the concentrations of those ions in the 
leachate (Kulli et al., 2003; Zhang et al., 2006). In both compacted and non-compacted soil, chloride leaching decreased with time and sulfate concentration was below the detection limit in the third leachates for $\mathrm{C}, \mathrm{NC}, \mathrm{C}-\mathrm{Cd}$ and $\mathrm{NC}-\mathrm{Cd}$. When the phosphate fertilizer was added, both chloride and sulfate concentrations in the leachate of NC-P were more twice greater than those of C-P. That sulfate concentration is higher in leachates of soil columns treated with the phosphate fertilizer is expected since the latter contains 41\%wt SO (Azzi et al. 2016) (Fig. 3c). Moreover, no soluble cadmium was found in those leachates because of the immobilization of available $\mathrm{Cd}$ by sulfate and/or phosphate.

Both $\mathrm{Cd}$ availability and $\mathrm{Cd}$ uptake by plant are significantly influenced by soil pH (Kirkham, 2006). Previous studies indicated that low $\mathrm{pH}$ values enhance $\mathrm{Cd}$ accumulation in plant tissues (Tsadilas et al., 2005; Waisberg et al., 2004; Yanai et al., 2006). A linear relationship between soil $\mathrm{pH}$ and cadmium absorption has even been reported (Christensen 1989, Tudoreanu and Phillips, 2004). Therefore, a low $\mathrm{pH}$ increases the concentration of cadmium ions available to root uptake.

\subsection{Cd transfer to lettuce}

The Cd concentration in shoots and roots of lettuce for all soil treatments is shown in Fig. 4. The cadmium content in plant tissues grown in soil without $\mathrm{Cd}$ addition reflects the geochemical background level. Cd contents were similar between roots and shoots (Fig. 4). In contrast, in soils where Cd was added, root tissues and plant shoots accumulated the highest amount of Cd of all soil treatments. Furthermore, the increase in cadmium in shoots and roots was found to be associated with the increase in chlorophyll content (Table 4, Fig. 4). Similar results were for tumbleweed, wheat, cucumber, sorghum and corn (Castillo-Michel et al., 2009; De la Rosa et al., 2004; De la Rosa et al., 2005; Youn-Joo, 2004). 
Cd concentration in shoots and roots increased when $\mathrm{Cd}$ was added to soils with or without fertilizer amendment. Phosphate addition to the soil contaminated by $\mathrm{Cd}$ led to a decrease in the Cd concentration of shoots and roots (Fig. 4). Unexpectedly, the phosphate fertilizer did not show significant effects on cadmium retention into the soil whatever the soil density. Previous studies revealed that the total $\mathrm{Cd}$ accumulation in Mirabilis jalapa, Chinese flowering cabbage (Brassica parachinensis L.), cauliflowers (Brassica oleracea L.) and spinach (Spinacia oleracea L.) significantly decreased after phosphate amendment (Chen et al., 2006; Dheri et al., 2007; Qiu et al., 2011; Yu and Zhou 2009), Cd being retained in soil as $\mathrm{Cd}_{3}\left(\mathrm{PO}_{4}\right)_{2}$ deposits (Bolan et al., 2003a; Bolan et al., 2003b; Hong et al., 2008; Hong et al., 2010). The soil compaction enhanced Cd accumulation in shoots by $12 \%$ for soils treated with $\mathrm{Cd}$, and by $25 \%$ for soils treated with $\mathrm{Cd}$ and P. Such accumulations might be attributed to the increase of root cells volume that improves nutrient uptake per root unit length (Rosolem et al., 2002).

The behaviours of $\mathrm{Zn}$ and $\mathrm{Pb}$ differ to that of cadmium in roots and shoots. The levels of $\mathrm{Zn}$ and $\mathrm{Pb}$ in shoot and root tissue of lettuce are shown in Fig. $4 \mathrm{c}-4 \mathrm{f}$. Pb levels varied between 3 and 33 mg. $\mathrm{kg}^{-1}$ and $\mathrm{Zn}$ levels between 21 and $115 \mathrm{mg} \cdot \mathrm{kg}^{-1}$ of dry weight tissue. On the whole, the $\mathrm{Zn}$ content in shoot was significantly reduced for the soils treated with phosphate and cadmium. Unexpectedly, the $\mathrm{Zn}$ concentration in roots increased for soils treated with $\mathrm{Cd}$ (C-Cd and NCCd) and decreased in roots grown for fertilized soils (C-P, NC-P, C-P-Cd and NC-P-Cd). The concentration of $\mathrm{Pb}$ in shoot for $\mathrm{P}$ treated soils clearly decreased without being necessary correlated to $\mathrm{P}$ addition. Nevertheless, in the presence of both cadmium and phosphate (C-P-Cd and NC-P-Cd), it seems that the cadmium phosphate complexation in the soil competes with the $\mathrm{Pb}$-phosphate interaction, and hence the $\mathrm{Pb}$ uptake by shoots was improved. On the other hand, $\mathrm{Pb}$ concentration was higher in roots of lettuce grown in $\mathrm{P}$ treated soil. Such result is in 
agreement with that of Cao et al. (2002) who observed a decrease in $\mathrm{Pb}$ concentration in St. Augustine grass (Stenotaphrum secundatum) tissue after $\mathrm{P}$ application to $\mathrm{Pb}$ contaminated soils. $\mathrm{Pb}-\mathrm{P}$ precipitates may form either on the root surface, within the root rhizosphere or in the bulk soil. However, soluble $\mathrm{P}$ decreases the concentrations of $\mathrm{Pb}, \mathrm{Zn}$ and $\mathrm{Cd}$ in plant tissue due to the formation of mixed-metal phosphates (Hettiarachchi and Pierzynski 2002). The same authors also reported that $\mathrm{P}$ addition decreased $\mathrm{Zn}$ concentration in cabbage shoots because of the formation of mixed-metal phosphates in soil.

Both Translocation factor $\left(\mathrm{F}_{\mathrm{T}}\right)$ and bioaccumulation factor $\left(\mathrm{F}_{\mathrm{B}}\right)$ were used to evaluate the effectiveness of lettuce in $\mathrm{Cd}$ translocation from roots to shoots and to evaluate its accumulation efficiency in the plants. Plants growing in compacted soils show significantly greater $F_{T}$ and $F_{B}$ than plants growing in non-compacted soils (Fig. 5). $\mathrm{F}_{\mathrm{T}}(\mathrm{Cd})$ decreased in soils treated with $\mathrm{Cd}$ (C-Cd and NC-Cd) and in soils treated with both $\mathrm{Cd}$ and P (C-P-Cd and NC-P-Cd), whereas $\mathrm{F}_{\mathrm{B}}$ for soils contaminated with $\mathrm{Cd}(0.81$ and 0.56 for $\mathrm{C}-\mathrm{Cd}$ and $\mathrm{NC}-\mathrm{Cd}$, respectively) were significantly higher when compared with soils treated with $\mathrm{P}$ and $\mathrm{Cd}(0.65$ and 0.42 for C-P-Cd and NC-P-Cd, respectively). The relative decline in total $\mathrm{Cd}$ uptake and in $\mathrm{Cd}$ translocation factor revealed that the presence of phosphate fertilizer in soil lowers the amount of cadmium uptake by lettuce. Hence, phosphate plays a significant role in $\mathrm{Cd}$ translocation from root to shoot. Such process involves the immobilization of $\mathrm{Cd}^{2+}$ by phosphate anions especially $\mathrm{HPO}_{4}{ }^{2-}$ onto cell walls by various mechanisms such as adsorption, complexation, precipitation, and crystallization. This leads to the formation of Cd-phosphate complexes which limits the mobility of Cd in plants (Jiang et al., 2007; Qiu et al. 2011). 


\section{CONCLUSIONS}

Soil compaction is a key factor in agriculture production because it deeply affects plants growth, phosphate fertilizer benefits and metals transfer between soil and plants. Actually, soil compaction led to a decrease in root length, chlorophyll content and NRA in Lactuca sativa. Furthermore, soil compaction enhanced the cadmium transfer to roots and shoots thus inducing an increased chlorophyll production. In cadmium contaminated soils, either compacted or not, phosphate fertilization inhibited the negative effect of cadmium on all the morphological parameters of plants. The fertilization had an antagonistic role both decreasing the chlorophyll content and increasing the NRA. Soil compaction and phosphate fertilization are considered key players for limiting Cd mobility in soil. However, a decrease in both chloride and sulfate concentrations of leachates were observed for compacted soil columns, whereas a net increase in nitrate was recorded at the same time. In soils contaminated with cadmium, a phosphate fertilizer addition is recommended to inhibit $\mathrm{Cd}$ accumulation in Lactuca sativa. Soil compaction increased both $\mathrm{Cd}$ translocation factor $\left(\mathrm{F}_{\mathrm{T}}\right)$ and bioaccumulation factor $\left(\mathrm{F}_{\mathrm{B}}\right)$. On the other hand, more attention must be paid to soil density that controls both cadmium availability and uptake by Lactuca sativa.

\section{ACKNOWLEDGMENTS}

This research was funded by research grant programs of the Lebanese University, the Lebanese Council for Scientific Research (CNRS) and the Lebanese Agriculture Research Institute (LARI). 


\section{REFERENCES}

Alameda, D., Villar, R., 2009. Moderate soil compaction: Implications on growth and architecture in seedlings of 17 woody plant species. Soil Tillage Res., 103, 325-331.

Alameda, D., Villar, R., 2012. Linking root traits to plant physiology and growth in Fraxinus angusifolia Vahl. seedlings under soil compaction conditions. Environ. Exp. Bot., 79, 49-57.

Al-Niemi, T.S., Kahn, M.L., McDermott, T.R., 1998. Phosphorus uptake by bean nodules. Plant Soil, 198, 71-78.

Arnon, D.I., 1949. Copper enzymes in isolated chloroplast. Polyphenoloxidase in Beta vulgaris. Plant Physiol., 24, 1-15.

Arvidsson, J., 1999. Nutrient uptake and growth of barley as affected by soil compaction. Plant Soil, 208, 9-19.

Assuero, S.G., Mollier, A., Pellerin, S., 2004. The decrease in growth of phosphorus-deficient maize leaves is related to a lower cell production. Plant, Cell Environ., 27, 887-895.

Barzegar, A.R., Asoodar, M.A., Ansari, M., 2000. Effectiveness of sugarcane residue incorporation at different water contents and the Proctor compaction loads in reducing soil compatibility. Soil Tillage Res., 57, 167-172.

Barzegar, A.R., Nadian, H., Heidari, F., Herbert, S.J., Hashemi, A.M., 2006. Interaction of soil compaction, phosphorus and zinc on clover growth and accumulation of phosphorus. Soil Tillage Res., 87, 155-162. 
Basta, N.T., Gradwohl, R., Snethen, K.L., Schroder, J.L., 2001. Chemical immobilisation of lead, zinc and cadmium in smelter contaminated soils using biosolids and rock phosphate. J. Environ. Qual. 30, 1222-1230.

Bolan, N.S., Adriano, D.C., Duraisamy, P., Mani, A., Arulmozhiselvan, K. $2003 a$. Immobilization and phytoavailability of cadmium in variable charge soils. I. Effect of phosphate addition. Plant Soil, 250, 83-94.

Bolan, N.S., Adriano, D.C., Naidu, R., 2003b. Role of phosphorus in (im)mobilization and bioavailability of heavy metals in the soil-plant system. Rev. Environ. Contam. Toxicol., 177, 144.

Campbell, W.H., 1999. Nitrate reductase structure, function and regulation: bridging the gap between biochemistry and physiology. Ann. Rev. Plant Physiol. Plant Mol. Biol., 50, 277-303.

Cao, X.D., Ma, Q.Y., Chen, M., Singh, S.P., Harris, W.G., 2002. Impacts of phosphate amendments on lead biogeochemistry at a contaminate site. Environ. Sci. Technol., 24, 52965304.

Castillo-Michel, H., Hernandez, N., Martinez-Martinez, A., Parsons, J., Peralta-Videa, J., Gardea-Torresdey, J., 2009. Coordination and speciation of cadmium in corn seedlings and its effects on macro- and micronutrients uptake. Plant Physiol. Biochem., 47, 608-614.

Chaffei, C., Pageau, K., Suzuki, A., Gouia, H., Ghorbel, M.H., Masclaux-Daubresse, C. 2004. Cadmium toxicity induced changes in nitrogen management in Lycopersicon esculentum leading to a metabolic safeguard through an amino acid storage strategy. Plant Cell Physiol., 45 (11), 1681-1693. 
Chen, S.B., Zhu, Y.G., Ma, Y.B., 2006. The effect of grain size of rock phosphate amendment on metal immobilization in contaminated soils. J. Hazard. Mater., B, 134, 74-79.

Chen, Y., Palta, J., Clements, J., Buirchell, B., Siddique, K., Rengel, Z., 2014. Root architecture alteration of narrow-leafed lupin and wheat in response to soil compaction. Field Crop Res., 165, $61-70$.

Chiera, J., Thomas, J., Rufty, T., 2002. Leaf initiation and development in soybean under phosphorus stress. J. Exp. Bot., 53 (368), 473-481.

Christensen, T.H., 1989 Cadmium soil sorption at low concentrations: VIII. Correlation with soil parameters. Water Air Soil Pollut., 44, 71-82.

DalCorso, G., Farinati, S., Maistri, S., Furini, A., 2008. How plants cope with cadmium: Staking all on metabolism and gene expression. J. Integr. Plant Biol., 50 (10), 1268-1280.

De la Rosa, G., Peralta-Videa, J.R., Montes, M., Parsons, J.G., Cano-Aguilera, I., GardeaTorresdey, J.L., 2004. Cadmium uptake and translocation in tumbleweed (Salsola kali), a potential Cd-hyperaccumulator desert plant species: ICP/OES and XAS studies. Chemosphere, $55,1159-1168$.

De la Rosa, G., Martinez-Martinez, A., Pelayo, H., Peralta-Videa, J.R., Sanchez-Salcido, B., Gardea-Torresdey, J.L. 2005. Production of low-molecular weight thiols as a response to cadmium uptake by tumbleweed (Salsola kali). Plant Physiol. Biochem., 43, 491-498.

Dheri, G.S., Brar, M.S., Malhi S.S., 2007. Influence of phosphorus application on growth and cadmium uptake of spinach in two cadmium-contaminated soils. J. Plant Nutr. Soil Sci., 170, 495-499. 
Dong, J., Wu, F., Zhang, G., 2005. Effect of cadmium on growth and photosynthesis of tomato seedlings. J. Zhejiang Univ. Sci. B, 6 (10), 974-980.

Durand, A., Piutti, S., Rue, M., Morel, J.L., Echevarria, G., Benizri, E. 2015. Improving nickel phytoextraction by co-cropping hyperaccumulator plants inoculated by plant growth promoting rhizobacteria. Plant Soil, http://dx.doi.org/10.1007/s11104-015-2691-2

François, M., Grant, C., Lambert, R., Sauvé, S., 2009. Prediction of cadmium and zinc concentration in wheat grain from soils affected by the application of phosphate fertilizers varying in Cd concentration. Nutr. Cycl. Agroecosyst., 83, 125-133.

Giuffré L., Ratto S., Marbán L., 1997. Heavy metals input with phosphate fertilizers used in Argentina. Sci. Total Environ., 204, 245-250.

Głąb, T., 2014. Effect of soil compaction and $\mathrm{N}$ fertilization on soil pore characteristics and physical quality of sandy loam soil under red clover/grass sward. Soil Tillage Res., 144, 8-19.

Goupil, P., Loncle, D., Druart, N., Bellettre, A., Rambour, S. 1998. Influence of ABA on nitrate reductase activity and carbohydrate metabolism in chicory roots (Cichorium intybus L.). J. Exp. Bot., 49 (328), 1855-1862.

Grant C.A., Bailey L.D., 1997. Effects of Phosphorus and Zinc Fertiliser Management on Cadmium Accumulation in Flaxseed. J. Sci. Food Agric., 73, 307-314.

Grant, C.A., Monreal, M.A., Irvine, R.B., Mohr, R.M., Mclaren, D.L., Khakbazan, M., 2010. Preceding crop and phosphorus fertilization affect cadmium and zinc concentration of flaxseed under conventional and reduced tillage. Plant Soil, 333, 337-350. 
Greger, M., Örgen, E., 1991. Direct and indirect effects of $\mathrm{Cd}^{2+}$ on photosynthesis in sugar beet (Beta vulgaris). Physiol. Plant., 83, 129-135.

Grzesiak, S., Grzesiak, M.T., Hura, T., Marcińiska, I., Rzepka, A., 2013. Changes in root system structure, leaf water potential and gas exchange of maize and triticale seedlings affected by soil compaction. Environ. Exp. Bot., 88, 2-10.

He, Q.B., Singh, B.R., 1994. Crop uptake of cadmium from phosphorus fertilizers: I. Yield and cadmium content. Water Air Soil Pollut., 74, 251-265.

Hettiarachchi, G.M., Pierzynski, G.M., 2002. In situ stabilization of soil lead using phosphorus and manganese oxide: Influence of plant growth. J. Environ. Qual., 31, 564-572.

Hong, C.O., Lee, D.K., Kim, P.J., 2008. Feasibility of phosphate fertilizer to immobilize cadmium in a field. Chemosphere, 70, 2009-2015.

Hong, C.O., Chung, D.Y., Lee, D.K., Kim, P.J., 2010. Comparison of phosphate materials for immobilizing cadmium in soil. Arch. Environ. Contam. Toxicol., 58, 268-274.

Huang, Z., A.N, Z., Chen, T., Lei, M., Xiao, X., Liao, X., 2007. Arsenic uptake and transport of Pteris vittata L. as influenced by phosphate and inorganic arsenic species under sand culture. J. Environ. Sci., 19, 714-718.

Jaworski, E.G., 1971. Nitrate reductase assay in intact plant tissue. Biochem. Bioph. Res. Co., 43 (6), 1274-1279.

Jeschke, W.D., Kirkby, E.A., Peuke, A.D., Pate, J.S., Hartung, W., 1997. Effects of P deficiency on assimilation and transport of nitrate and phosphate in intact plants of castor bean (Ricinus communis L.). J. Exp. Bot., 40 (306), 75-91. 
Jiang, H.M., Yang, J.C., Zhang, J.F., 2007. Effects of external phosphorus on the cell ultrastructure and the chlorophyll content of maize under cadmium and zinc stress. Environ. Pollut., 147, 750-756.

Jiao, W., Chen, W., Chang, A., Page, A., 2012. Environmental risks of trace elements associated with long-term phosphate fertilizers applications: A review. Environ. Pollut., 168, 44-53.

Jusoff, K. 1991. Effect of compaction of soils on growth of Acacia mangium Willd. under glasshouse conditions. New Forests, 5 (1), 61-66.

Karam, F., Mounzer, O., Sarkis, F., Lahoud, R., 2002. Yield and nitrogen recovery of lettuce under different irrigation regimes. J. Appl. Hort., 4, 70-76.

Kavanová, M., Lattanzi, F.A., Grimoldi, A.A., Schnyder, H., 2006. Phosphorus deficiency decreases cell division and elongation in grass leaves. Plant Physiol., 141, 766-775.

Kirkham, M.B., 2006. Cadmium in plants on polluted soils: Effects of soil factors, hyperaccumulation, and amendments. Geoderma, 137, 19-32.

Konôpka, B., Pagès, L., Doussan, C., 2008. Impact of soil compaction heterogeneity and moisture on maize (Zea mays L.) root and shoot development. Plant Soil Environ., 12, 509-519.

Kooistra, M.J., Schoonderbeek, D., Boone, F.R., Veen, B.W., Vannoordwijk, M., 1992. Rootsoil contact of maize, as measured by a thin-section technique. Effects of soil compaction. Plant Soil, 139, 119-129.

Kozlowski, T.T., 1999. Soil compaction and growth of woody plants. Scand. J. For. Res., 14, 596-619. 
Kratz, S., Schick, J., Schnug, E., 2016. Trace elements in rock phosphates and P containing mineral and organo-mineral fertilizers sold in Germany. Sci. Total Environ., 542, 1013-1019.

Kulli., B., Gysi, M., Flühler, H., 2003. Visualizing soil compaction based on flow pattern analysis. Soil Till. Res., 70 (1), 29-40.

Kuncoro, P.H., Koga, K., Satta, N., Muto, Y., 2014. A study on the effect of compaction on transport properties of soil gas and water I: Relative gas diffusivity, air permeability, and saturated hydraulic conductivity. Soil Tillage Res., 143, 172-179.

Lavado, R.S., Porcelli, C.A., Alvarez, R., 2001. Nutrient and heavy metal concentration and distribution in corn, soybean and wheat as affected by different tillage systems in the Argentine Pampas. Soil Tillage Res., 62, 55-60.

Lillo, C., 1994a. Light regulation of nitrate reductase in green leaves of higher plants. Physiol. Plant., 90, 616-620.

Lillo, C., 1994b. Light/dark regulation of higher plant nitrate reductase related to hysteresis and calcium/magnesium inhibition. Physiol. Plant., 91, 295-299.

Lipiec, J., Stępniewski, W., 1995. Effects of soil compaction and tillage systems on uptake and losses of nutrients. Soil Tillage Res., 35, 37-52.

Lipiec, J., Hom, R., Piertrusiewicz, J., Siczek, A., 2012. Effects of soil compaction on root elongation and anatomy of different cereal plant species. Soil Tillage Res., 121, 74-81.

Luo, L., Ma, Y., Zhang, S., Wei, D., Zhu, Y., 2009. An inventory of trace element inputs to agricultural soils in China. J. Environ. Manage., 90, 2524-2530. 
Manios, T., Stentiford, E.I., Millner, P.A. 2003. The effect of heavy metals accumulation on the chlorophyll concentration of Typha latifolia plants, growing in a substrate containing sewage sludge compost and watered with metaliferus water. Ecol. Eng., 20, 65-74.

Miransari, M., Bahrami, H.A., Rejali, F., Malakouti, M.J., 2009. Effects of soil compaction and arbuscular mycorrhiza on corn (Zea mays L.) nutrient uptake. Soil Tillage Res., 103, 282-290.

Naeem, M., Khan, M.M.A., Moinuddin, Idrees, M., Aftab, T., 2010. Phosphorus ameliorates crop productivity, photosynthetic efficiency, nitrogen-fixation, activities of the enzymes and content of nutraceuticals of Lablab purpureus L. Sci. Hortic., 126, 205-214.

Naidu, R., Bolan, N.S., Kookana, R.S., Tiller, K.G., 1994. Ionic strength and pH effects on the adsorption of cadmium and the surface charge of soils. Eur. J. Soil Sci., 45, 419-429.

Nicholson, F.A., Smith Sr., Alloway, B.J., Carlton-Smith, C., Chambers, B.J., 2003. An inventory of heavy metals inputs to agricultural soils in England and Wales, Sci.Total Envir., 311, $1-3,205-219$.

Qiu, Q., Wang, Y., Yang, Z., Yuan, J., 2011. Effects of phosphorus supplied in soil on subcellular distribution and chemical forms of cadmium in two Chinese flowering cabbage (Brassica parachinensis L.) cultivars differing in cadmium accumulation. Food Chem. Toxicol., 49, 2260-2267.

Renella, G., Mench, M., Lelie, D. Van Der, Pietramellara, G., Ascher, J., Ceccherini, M. T., Landi, L., Nannipieri, P., 2004. Hydrolase activity, microbial biomass and community structure in long-term Cd-contaminated soils. Soil Biol. Biochem., 36, 443-451.

Rich, C., Gronow, J., Voulvoulis, N., 2008. The potential for aeration of MSW landfills to accelerate completion. Waste Manage., 28, 1039-1048. 
Rodriguez, D., Keltjens, W.G., Goudriaan, J., 1998. Plant leaf area expansion and assimilate production in wheat (Triticum aestivum L.) growing under low phosphorus conditions. Plant Soil, $200,227-240$.

Rosolem, C.A., Foloni, J.S.S., Tiritan, C.S., 2002. Root growth and nutrient accumulation in cover crops as affected by soil compaction. Soil Till. Res., 65, 109-115.

Rufty JR, T.W., Israel, Q.W., Volk, R.J., Qiu, J., Sa, T., 1993. Phosphate regulation of nitrate assimilation in soybean. J. Exp. Bot., 44 (5), 879-891.

Skórzyńska-Polit, E. and Baszyński, T., 1997. Differences in sensitivity of the photosynthetic apparatus in Cd-stressed runner bean plants in relation to their age. Plant Sci., 128, 11-21.

Summerfelt, S.T., Davidson, J., Waldrop, T., 2003. Evaluation of full-scale carbon dioxide stripping columns in a coldwater recirculating system. Aquac. Eng., 28, 155-169.

Tsadilas, C.D., Karaivazoglou, N.A., Tsotsolis, N.C., Stamatiadis, S., Samaras, V., 2005. Cadmium uptake by tobacco as affected by liming, $\mathrm{N}$ form, and year of cultivation. Environ. Pollut., 134, 239-246.

Tudoreanu, L., Phillips, C.J.V., 2004. Empirical models of cadmium accumulation in maize, rye grass and soya bean plants. J. Sci. Food Agr., 84, 845-852.

Waisberg, M., Black, W.D., Waisberg, C.M., Hale, B., 2004. The effect of pH, time and dietary source of cadmium on the bioaccessibility and adsorption of cadmium to/from lettuce (Lactuca sativa L. cv. Ostinata). Food Chem. Toxicol., 42, 835-842.

Williams, C.H., David, D.J., 1976. The accumulation in soil of cadmium residues from phosphate fertilizers and their effect on the cadmium content of plants. J. Soil Sci., 121, 86-93. 
Yanai, J., Zhao, F.J., McGrath, S.P., Kosaki, T., 2006. Effect of soil characteristics on Cd uptake by the hyperaccumulator Thlaspi caerulescens. Environ. Pollut., 139, 167-175.

Youn-Joo, A., 2004. Soil ecotoxicity assessment using cadmium sensitive plants. Environ. Pollut., 127, 21-26.

Yu, Z., Zhou, Q., 2009. Growth responses and cadmium accumulation of Mirabilis jalapa L. under interaction between cadmium and phosphorus. J. Hazard. Mater., 167, 38-43.

Zhang, S., Grip., H., Lövdahl, L., 2006. Effect of soil compaction on hydraulic properties of two loess soils in China. Soil Till. Res., 90, 117-125.

Zhao, F.-J., Lopez-Bellido, F.J., Gray, C.W., Whalley W.R., Clarck, L.J., McGrath, S.P., 2007. Effects of soil compaction and irrigation on the concentrations of selenium and arsenic in wheat grains., Sci.Total Envir., 372, 433-439. 